\title{
A Biological Treatment Technique for Wool Textile
}

\author{
Xiao-Wei Yu, Wen-Jun Guan, Yong-Quan Li*, Ting-Jing Guo and Ji-Dong Zhou \\ College of Life Science, Zhejiang University; Hangzhou310027; P. R. China
}

\begin{abstract}
A biological treatment technique for wool textile was carried out by enzymes degradation coupled with $\mathrm{H}_{2} \mathrm{O}_{2}$ oxidation. The results demonstrated that the technique had ideal effects on wool textile such as better softness, plump and less loss of bursting stress. Because of mild reaction conditions, less textile damage and less environmental pollution, this technique for wool textile treatment could have promising prospect.
\end{abstract}

Key words: Wool textile decrement, oxidation pretreatment, enzyme degradation, L86 enzymes

\section{INTRODUCTION}

It is necessary for the wool industry to use more environmentally friendly finishing processes due to the pollutant in the process of chemical treatment. Wool mainly consists of scaly layer and cortex layer, both adhering to each other through cellular matrix carboxymethyl cellulose (CMC). Scaly layer is composed of surface layer, outer layer and inner layer, which is approximately $10 \%$ of total wool weight (Word et al., 1993; Messinger et al., 1994). During the processing the scaly layer of wool is peeled off partly or completely by digestion in order to raise the wool fineness shine, softness and elasticity. Surface layer and outer layer of wool contain abundant keratin protein, which are too tight to be degraded; whereas inner layer contains non-keratin protein, which are easy to be digested by protease; cellular matrix CMC is similarly easy to be degraded by cellulase (Leeder et al., 1968).

Traditional oxidizers such as $\mathrm{NaClO}$ and $\mathrm{KMnO}_{4}$ are used to break the surface layer and outer layer of the scaly layer by oxidizing the disulfide bond in keratin proteins. However, their strong oxidations are always difficult to control and often result in disproportion of the treatment. Moreover, $\mathrm{NaClO}$ reaction with wool produces halogenide. Thus, chemical oxidizes are not suitable. Experimental results in this paper proved that $\mathrm{H}_{2} \mathrm{O}_{2}$ was a suitable oxidizer, since it could give oxygen smoothly with moderate oxidization. The mechanism of oxidation is shown in scheme 1 .

Therefore, less aggressive chemical processes and environmentally friendly methods such as enzyme based processes, as well as combination treatments have gained widespread acceptance (Cortez et al., 2002; Jose et al., 1996; Manjrekar, 1995; Shridhar et al., 1995), which impart desirable properties, such as improving handle properties and imparting shrink-resistance and produce less pollution (Breier et al.,1999; Bishop et al.,1998; Heine et al.,2001). Generally $\mathrm{H}_{2} \mathrm{O}_{2}$ is applied to break the surface layer and outer layer of the scaly layer; Then, Aspergillus usamii L86 enzymes including acid protease and CMCase (Yongquan Li,2001) are added to degrade inner layer and outer layer in order to peel off the scaly layer effectively.

*Author for correspondence 


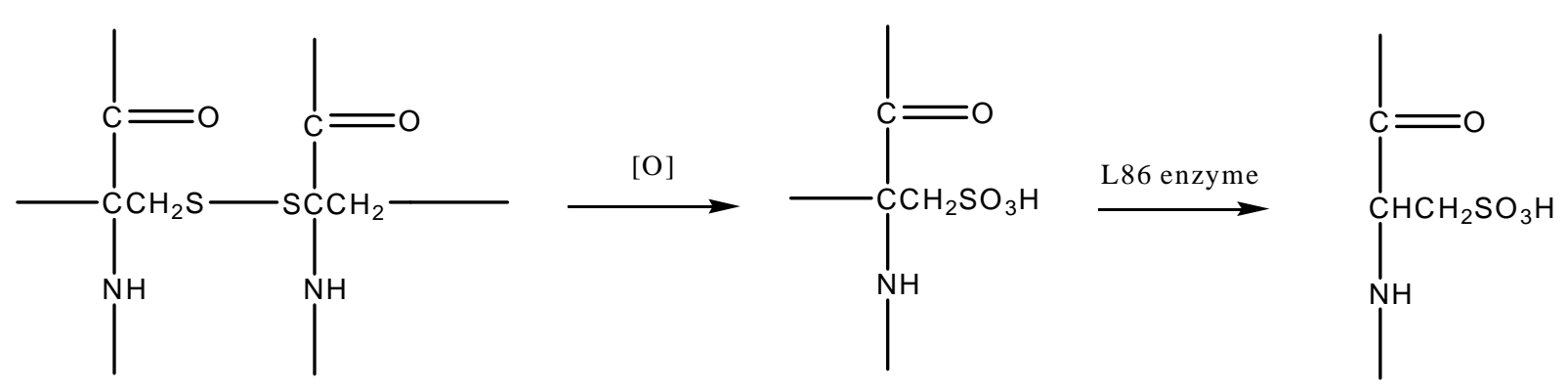

Scheme 1 - The mechanism of oxidation by $\mathrm{H}_{2} \mathrm{O}_{2}$ and enzymes.

\section{MATERIALS AND METHODS}

\section{Experimental Materials}

Knitted fabric was made from $100 \%$ Australia wool, whose size was $22 \mathrm{~cm} * 16 \mathrm{~cm}$, transverse 54 needles $/ \mathrm{cm}$ and longitudinal 78 lines $/ 10 \mathrm{~cm}$.

\section{Process of treatment}

After $\mathrm{H}_{2} \mathrm{O}_{2}$ oxidation pretreatment, the wool textile was degraded with L86 enzymes, followed by neutralization with alkali, washing and aminosilicone oil Umd softening treatment $(18 \mathrm{~g} / \mathrm{L}$ of Umd, $\mathrm{pH} 5-6,20-30^{\circ} \mathrm{C}$ for $10 \mathrm{~min}$ ), and finally, the treated wool textile was washed and dried at $80^{\circ} \mathrm{C}$.

\section{$\mathrm{H}_{2} \mathrm{O}_{2}$ oxidation}

All experiments were carried out under the conditions of the dissolvent proportion of 1:30 and $2.0 \mathrm{~g} / \mathrm{L}$ of penetrate reagent. For observing influence of $\mathrm{H}_{2} \mathrm{O}_{2}$ oxidation on wool textile, reaction temperature and $\mathrm{pH}$ were at $20^{\circ} \mathrm{C}, \mathrm{pH} 4.0$ for 40 min; $\mathrm{H}_{2} \mathrm{O}_{2}$ concentration $40 \mathrm{~g} / \mathrm{L}, \mathrm{pH} 4.0$ for $40 \mathrm{~min}$, and at $20^{\circ} \mathrm{C}, \mathrm{H}_{2} \mathrm{O}_{2}$ concentration $40 \mathrm{~g} / \mathrm{L}$ and ratio at $6.0 \%$.

\section{Biological treatment with respectively enzymes} Under the conditions of dissolvent proportion of $1: 30$, reaction temperature $40^{\circ} \mathrm{C}$ and $\mathrm{pH} 4.0$ according to the enzymatic characteristics of acid protease and CMCase (Xinghua,Wen, 1999), the L86 enzymes containing acid protease and CMCase were added to degrade the inner layer, and add $\mathrm{NaHSO}_{3}$ at the same time.

\section{Acid protease measurement}

Folin method was applied in the enzyme activity assay (Yongquan Li, 1999). Under the conditions of $\mathrm{pH} 3.0$ and $40^{\circ} \mathrm{C}$, one unit of acid protease was defined as $1 \mu \mathrm{g}$ tyrosine produced by hydrolysis of casein per minute.

\section{CMCase measurement}

CMC saccharimetry was applied in the enzyme activity assay (Shuzheng Zhang, 1984). Under the conditions of pH5.0 and $50^{\circ} \mathrm{C}$, one unit of CMCase was defined as $1 \mu \mathrm{g}$ CMC hydrolyzed per minute.

\section{Bending stiffness}

Bending stiffness was measured with Instron 1122 Strength Electronic Instrument.

\section{Bursting Strength}

The strength of wool textile (measure unit $\mathrm{N} / \mathrm{cm}^{2}$ ) was determined with Textile Bursting Strength Instrument.

\section{Decrement ratio} $\begin{array}{ll}\text { Decrement } & \begin{array}{l}\text { Dry weight before treatment-dry } \\ \text { weight after treatment }\end{array} \\ \text { ratio }= & \end{array}$

Dry weight before treatment

Untreated wool textile was dried at $105^{\circ} \mathrm{C}$. Then, it was treated with decrement and dried. The decrement ratio was calculated:

Each test was conducted at least three times. Data are the means of three replications. Significantly different from replications was at $\mathrm{p}<0.05$. 


\section{RESULTS AND ANALYSIS}

\section{Technique of oxidation pretreatment}

The relationships between the concentration of $\mathrm{H}_{2} \mathrm{O}_{2}$ and bursting strength loss ratio, decrement ratio are illustrated in Fig. 1. The results indicated that when the concentration of $\mathrm{H}_{2} \mathrm{O}_{2}$ was between 40 and $50 \mathrm{~g} / \mathrm{L}$, the decrement ratio arrived was
6-8\% with the textile bursting strength loss ratio within $10 \%$ and the wool textile was soft, plump and smooth.

The experiment about effect of reaction temperature on decrement ratio showed (Fig 2) that the speed of $\mathrm{H}_{2} \mathrm{O}_{2}$ oxidation was slow below $20^{\circ} \mathrm{C}$.

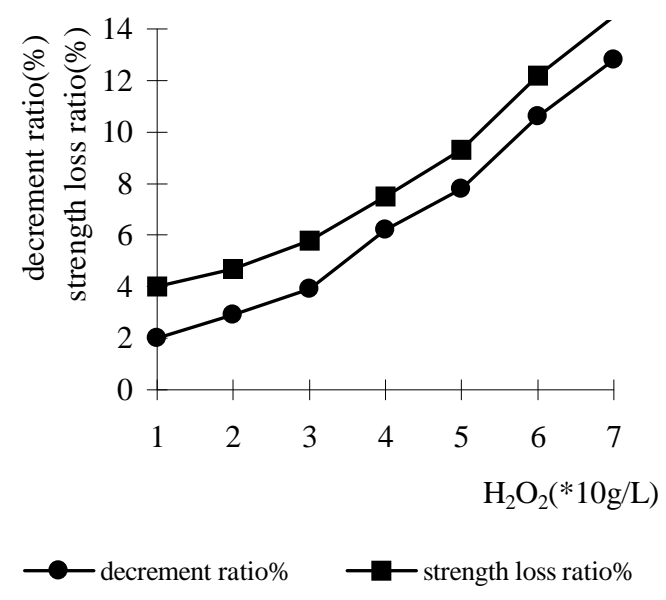

Figure 1 - Effects of $\mathrm{H}_{2} \mathrm{O}_{2}$ concentration on the pretreatment of wool textile. The reaction conditions were at $20^{\circ} \mathrm{C}, \mathrm{pH} 4.0$ for $40 \mathrm{~min}$.

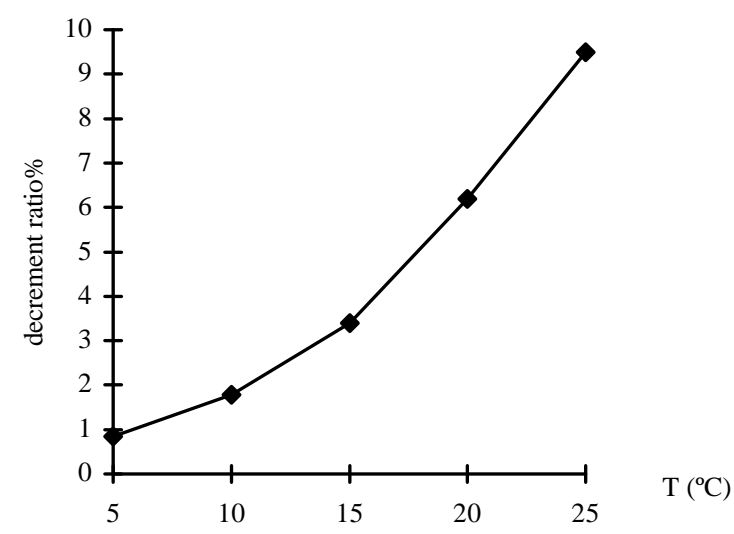

Figure 2 - Effects of reaction temperature on decrement ratio. The reaction conditions were at $\mathrm{H} 2 \mathrm{O} 2$ concentration $40 \mathrm{~g} / \mathrm{L}, \mathrm{pH} 4.0$ for $40 \mathrm{~min}$.

However, the reaction speed was increased above $20^{\circ} \mathrm{C}$, but it damaged the strength of wool textile intensively and made the wool textile fragile and faint, so the temperature should be controlled strictly at $20^{\circ} \mathrm{C}$ in pretreatment process. 
Fig. 3 showed the $\mathrm{pH}$ effect on pretreatment reaction. The results revealed that the $\mathrm{H}_{2} \mathrm{O}_{2}$ oxidation reaction was hardly processed at $\mathrm{pH}>6.5$. While at $\mathrm{pH}<2.0, \quad \mathrm{H}_{2} \mathrm{O}_{2}$ reaction finished completely within $20 \mathrm{~min}$ (decrement ratio at $6.0 \%$ ); and if the reaction time was beyond $30 \mathrm{~min}$, the effects of the treatment were not fairly proportioned (decrement ratio $>10 \%$, bursting strength loss ratio $>12 \%$ ). However, controlling $\mathrm{pH}$ 4.0 and reaction time $45 \mathrm{~min}$, the decrement ratio also could reach at $6.0 \%$. Thus, the pretreatment condition was selected as $40 \mathrm{~g} / \mathrm{L}$ of $\mathrm{H}_{2} \mathrm{O}_{2}$ concentration, reaction time $45 \mathrm{~min}$ and $\mathrm{pH}$ 4.0.

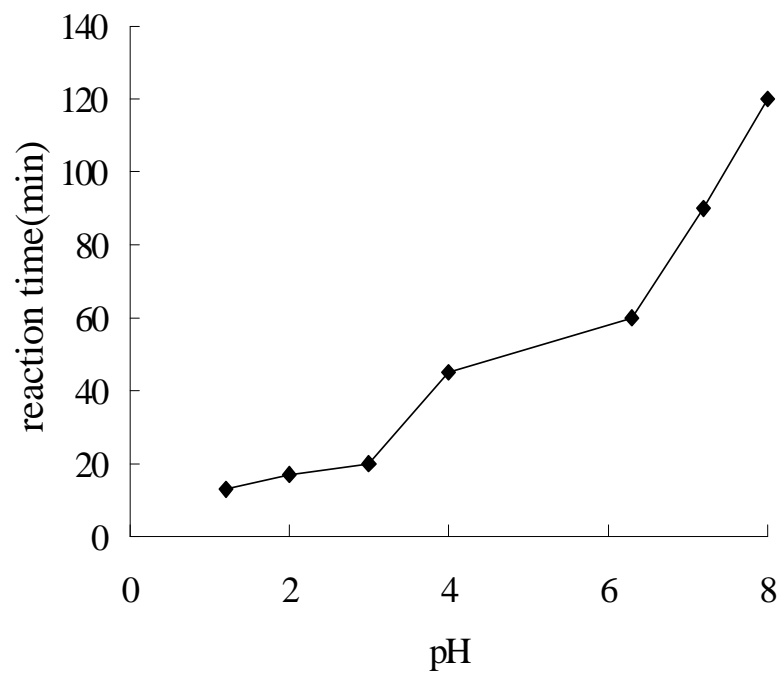

Figure 3 - Effects of $\mathrm{pH}$ on time of $\mathrm{H}_{2} \mathrm{O}_{2}$ oxidation reaction. The reaction conditions were at $\mathrm{H}_{2} \mathrm{O}_{2}$ concentration $40 \mathrm{~g} / \mathrm{L}, 20^{\circ} \mathrm{C}$, and ratio at $6.0 \%$.

\section{Enzymatic degradation}

The supernatant from Aspergillums usamii L86's fermentation broth containing acid protease $(10000 \mathrm{U} / \mathrm{ml})$ and CMCase $(3600 \mathrm{U} / \mathrm{ml})$ was used as treating reagent. After the oxidation pretreatment at the conditions of $40 \mathrm{~g} / \mathrm{L}$ of $\mathrm{H}_{2} \mathrm{O}_{2}, \mathrm{pH} 4.0,20^{\circ} \mathrm{C}$ and $45 \mathrm{~min}$ of reaction time, the L86 enzymes containing acid protease and CMCase were added to degrade the inner layer. CMCase acted on the cellular matrix between scaly layer and cortex layer, which could help peeling off the scaly layer, so as to reinforce the effect of acid protease degradation. In order to optimize the enzyme degradation process, an L9 $\left(3^{4}\right)$ orthogonal test was carried out, in which the amount of enzyme solution, the concentration of $\mathrm{NaHSO}_{3}$ and the reaction time were taken as experimental parameters.

The results are shown in Table 1, which showed that reaction time influenced the results most significantly and the enzyme concentration followed. The reaction time represented the influence of enzyme degradation on the decrement ratio, the longer the treatment time, the stronger the degradation reaction.

While it was treated for $60 \mathrm{~min}$, the effect of decrement was quite good, but too much loss of textile strength, so the suitable reaction time was selected as 45 min. $\mathrm{NaHSO}_{3}$ in solution had two functions, one was to decompose the disulfide bond in the wool, which would raise the speed of enzyme degradation; the other was to reduce residue of $\mathrm{H}_{2} \mathrm{O}_{2}$ in the solution, because the residue of $\mathrm{H}_{2} \mathrm{O}_{2}$ would injure the wool gradually and influence the whiteness of textile. The results demonstrated that the suitable concentration of $\mathrm{NaHSO}_{3}$ was $60 \mathrm{~g} / \mathrm{L}$, and increasing the concentration of protease could increase the textile decrement ratio with bursting strength decreased. However, there was a twophase reaction of solid-liquid on wool surface, when the enzyme concentration reached at a certain amount, the wool surface was saturated and 
reaction was efficiency. By adding more enzymes into solution, the reaction speed could not be increased. Considering the reaction effect and the material cost, the suitable amount of enzymes was selected as $1.5 \mathrm{ml}$ of per liter solution.
The optimum conditions of enzyme degradation process were $1.5 \mathrm{ml}$ of enzymes of per liter solution and its final concentration arrived at $15 \mathrm{U} / \mathrm{ml}$ of acid protease and $5 \mathrm{U} / \mathrm{ml}$ of CMCase, $60 \mathrm{~g} / \mathrm{L}$ of $\mathrm{NaHSO}_{3}$, the reaction time $45 \mathrm{~min}$, dissolvent proportion $1: 30,40^{\circ} \mathrm{C}, \mathrm{pH} 4.0$.

Table 1 - Orthogonal Test of enzyme degradation and extreme value analyses

\begin{tabular}{cccccc}
\hline $\mathbf{N}^{\mathbf{0}}$ & \multicolumn{3}{c}{ Test factors } & \multicolumn{2}{c}{ Experiment results } \\
\hline & Enzymes (ml) & $\mathrm{NaHSO}_{3}(* 10 \mathrm{~g} / \mathrm{L})$ & Time (min) & Bursting Strength $\left(\mathrm{N} / \mathrm{cm}^{2}\right)$ & Decrement ratio (\%) \\
1 & 1.0 & 4.0 & 30 & 57.18 & 5.8 \\
2 & 1.0 & 6.0 & 45 & 49.02 & 7.4 \\
3 & 1.0 & 8.0 & 60 & 38.34 & 7.6 \\
4 & 1.5 & 4.0 & 45 & 52.18 & 7.9 \\
5 & 1.5 & 6.0 & 60 & 45.42 & 8.7 \\
6 & 1.5 & 8.0 & 30 & 47.21 & 7.2 \\
7 & 2.0 & 4.0 & 60 & 40.68 & 8.5 \\
8 & 2.0 & 6.0 & 30 & 52.07 & 8.3 \\
9 & 2.0 & 8.0 & 45 & 34.96 & \\
$\mathrm{~K}_{1}$ & 20.8 & 22.2 & 20.4 & & \\
$\mathrm{~K}_{2}$ & 23.8 & 23.7 & 23.6 & & \\
$\mathrm{~K}_{3}$ & 24.2 & 22.9 & 24.8 & & \\
$\mathrm{R}$ & 3.4 & 1.5 & 4.4 & & \\
\hline
\end{tabular}

Table 2 - The conditions and results of contrast experiment

\begin{tabular}{|c|c|c|c|c|}
\hline \multirow[b]{2}{*}{$\mathbf{N}^{\mathbf{o}}$} & \multirow[b]{2}{*}{ Test Method } & \multicolumn{3}{|c|}{ Experiment Results } \\
\hline & & $\begin{array}{c}\text { Decrement ratio } \\
(\%)\end{array}$ & $\begin{array}{c}\text { Bending stiffness } \\
\text { (N/cm) }\end{array}$ & $\begin{array}{c}\text { Bursting strength } \\
\left(\mathrm{N} / \mathrm{cm}^{2}\right)\end{array}$ \\
\hline 10 & Enzyme degradation $^{\mathrm{a}}$ & 4.5 & 0.305 & 63.68 \\
\hline 11 & $\mathrm{H}_{2} \mathrm{O}_{2}$ oxidation $^{\mathrm{b}}$ & 7.2 & 0.274 & 50.97 \\
\hline 12 & $\begin{array}{l}\text { Coupling treatment } \\
\text { process }\end{array}$ & 8.8 & 0.213 & 46.52 \\
\hline
\end{tabular}

Experimental conditions : ${ }^{\mathrm{a}} 1.5 \mathrm{ml} / \mathrm{L}$ of enzymes per liter solution, $\mathrm{NaHSO}_{3} 60 \mathrm{~g} / \mathrm{L}, \mathrm{pH} 4.0,40^{\circ} \mathrm{C}$, dissolvent proportion 1:30 for 90min;

${ }^{\mathrm{b}} \mathrm{H}_{2} \mathrm{O}_{2} 40 \mathrm{~g} / \mathrm{L}$, penetrate agent $2.0 \mathrm{~g} / \mathrm{L}, 20^{\circ} \mathrm{C}, \mathrm{pH}=4.0$; dissolvent proportion 1:30 for $90 \mathrm{~min}$;

${ }^{\mathrm{c}} \mathrm{H}_{2} \mathrm{O}_{2}$ oxidation conditions were like No11, for $45 \mathrm{~min}$;enzyme degradation conditions were like No10, for $45 \mathrm{~min}$

\section{Contrast experiment}

In order to show the characteristics of enzyme degradation coupled with $\mathrm{H}_{2} \mathrm{O}_{2}$ oxidation, the contrast experiment about enzyme degradation, $\mathrm{H}_{2} \mathrm{O}_{2}$ oxidation pretreatment and enzyme degradation coupled with $\mathrm{H}_{2} \mathrm{O}_{2}$ oxidation were carried out and the decrement ratio, bending stiffness and bursting strength were selected as responsive values. The test conditions and results are shown in Table 2. 
Apparently the coupled treatment process provided better decrement effect with satisfying decrement ratio, bursting strength and softness than that of $\mathrm{H}_{2} \mathrm{O}_{2}$ oxidation or enzyme degradation alone. Furthermore, after coupling treatment, washing and drying, the treated wool textile showed good strength and softness, and clear printing pattern. While treated with $\mathrm{H}_{2} \mathrm{O}_{2}$ oxidation or enzyme degradation alone, the textile showed relatively bad strength, softness and feel of handle.

After the treatment by enzyme degradation coupled with $\mathrm{H}_{2} \mathrm{O}_{2}$ oxidation, the wool textile should be washed, avoiding the peptides and carbonaceous matters adhering to textile, which were produced by enzyme degradation. Then, temperature should be raised to $80^{\circ} \mathrm{C}$ so as to deactivate enzyme and dry wool textile. When the scaly layer of wool was peeled off, the wool textile showed plump and softness but bad elasticity, and the cortex layer would be influenced easily by many chemistry reagents and weather conditions, therefore softener with affinity to wool, amino-silicone oil Umd, had to use to form a protective membrane covering the wool surface.

The technique of biological treatment was studied according to the subtle structure of wool. The enzyme degradation had mild reaction conditions and could be controlled easily. The enzymes from strain Aspergillums L86, whose components (two enzymes) interrelated with the structure of wool closely and had the same $\mathrm{pH}$ of decrement process, improved the effects of treatment remarkably (Yongquan Li, 2001). Hence the effect of coupling treatment process was better than that of traditional chemistry treatment. For example, it greatly improved the quality of treated textile, and produced less environment pollution.

Since $\mathrm{H}_{2} \mathrm{O}_{2}$ oxidation and enzyme degradation required the same $\mathrm{pH}$, when these two processes were combined, the solution needed not be changed during process. Thus, using this technique could cut down the material cost and manpower.

\section{ACKNOWLEDGEMENTS}

This work was supported by Science Research Plan of Zhejiang Province in China (No.99-3-031).

\section{REFERENCES}

Bishop, D.; Shen, J.; Heine; E. and Hollfelder, B. (1998), The use of proteolytic enzymes to reduce wool-fibre stiffness and prickle. J. Text Inst., 89, 546-553.

Breier, R. and Eugen, P. (1999), Felt-free finishing of wool using proteolytic enzyme, useful for flocks, slubbing, yarn and fabric. DE19807456.

Cortez, J.; Bonner, P. L. R. and Griffin, M. (2002), A method for enzymatic treatment of textiles. WO0204739.

Heine, E.; Hartwig, H. and Lone, D. (2001), Method for enzymatic treatment of wool. US2001003220.

Jose, C. (1996), The state of the art in textile biotechnology. J. Soc. Dyers and Colorists, 112, 326-329.

Leeder, J. D. and Bradbury, J. H. (1968), Conformation of epicuticle on keratin fibres. Nature, 218, 694-695.

Manjrekar, S. G. (1995), Application of enzymes in wet process an overview. J. Textile Assn., 60, 79-87.

Messinger, H.; Hocker, H. and Zahn, H. (1994), Covalently linked fatty acids at the surface of wool: part of the cuticle cell envelope. Textile Res. J., 64, 554-555.

Shridhar, V. C.; Samina, K. and Mehta, R. D. (1995), Effect of bio-finishing on cotton/wool blended fabrics. Textile Res. J., 65, 564-569.

Shuzheng Zhang (1984), Enzyme preparation industry, Beijing: Science Press. pp. 387-413.

Word, R. J.; Willis, H. A.; George, G. A.; Guise, G. B.; Denning, R.; Evans, D. J. and Short, R. (1993), Surface analysis of wool by $\mathrm{x}$-ray photoelectron spectroscopy and static secondary mass spectrometry. Textile Res. J., 63, 362-368.

Xinghua Wen; Yongquan $\mathrm{Li}$ and Chenming $\mathrm{Xu}$ (1999), Studies on the kinetic property of acid protease from Aspergillus usamii mutant. Mycosystem, 18, 66-71.

Yongquan Li (2001), Screening of compound enzymes high productive strain L86 for wool textile decrement by laser irradiation Mycosystema, 20, 196-200.

Yongquan Li; Xinghua Wen and Xiaolong He (1999), Studies on the screening high yield acid protease producing strain L336 by combining microwave irradiation with chemical inducing. Acta Microbio. Sinica, 39, 181-184. 